Further Education Sector Governors as Ethnographers: Five Case Studies.

Dr Andrew Clapham*

Dr Rob Vickers

Nottingham Institute of Education

Nottingham Trent University

Clifton Lane

Nottingham

NG11 8NS

* Email: andrew.clapham@ntu.ac.uk 


\section{Further Education Sector Governors as Ethnographers: five case studies.}

Dr Andrew Clapham*

Dr Rob Vickers

School of Education

Nottingham Trent University

This paper considers how governors in the English Further Education and Skills (FE) sector examined their practice as ethnographers. The paper locates both FE governance and ethnography within the challenges of the performative and Panoptic environments facing English education (Lyotard, 1977; Foucault, 1979; Ball, 2003). In doing so, the paper explores how the informants' mobilisation of ethnographic methods revealed a novel lens on both governance and the role of ethnographer. Employing Grounded Theory (Glaser and Strauss, 1967), the paper considers how the participants negotiated philosophical questions regarding evidence, objectivity and truth. The paper suggests that despite the deep seated complexities inherent with conducting ethnography in performative contexts, the participants generated data which painted a unique and revealing picture upon their practice as governor and researcher.

Keywords: innovative; governance; performativity; policy; enactment

\section{Introduction}

At first, I was really concerned about 'doing it wrong'. You see, I'm a business man at heart, I deal in 'hard' stuff like profit and loss figures. So...well, I wanted to be as scientific as I could about this. So I created a way of measuring who said what, and how many times they said it. And this was really good... at first. And then I realised I was missing the point. I started to notice not who was saying stuff, but who wasn't. I started to notice the pauses, the silences. I started to notice who sat next to who, I started to notice who got to the meeting first, who staked their claim on the power seats. And then it hit me...I had always noticed this stuff... (Ian, interview)

The above narrative gives a glimpse as to the focus of this paper, a paper which reports 
on how four key informants explored innovative governance ${ }^{1}$ through their role as 'governor ethnographers'. The examination of educational leadership outside of the school is an under-researched area of enquiry (see though Kelly et al, 2006; Morrison and Lumby, 2009; Gleeson et al, 2009). This paper seeks to begin to redress this imbalance through reporting on a twelve-month project that sought to examine educational leadership outside the school through the work, and experiences, of governor ethnographers sitting on the boards of educational organisations.

The setting is the English Further Education and Skills sector $(\mathrm{FE})^{2}$ although one of the governor ethnographers, Oliver ${ }^{3}$, came to be the project as an outsider to the sector. So as to 'drill down' into the day-to-day workings of FE governance, the paper reports on a novel methodological approach and in doing so it explores the fundamental question whether, as Feather (2012) asks, there is a desire to conduct research in FE.

The paper draws on the work of Morrison and Lumby (2009) who, over fifteen years ago, used ethnography to explore leadership in FE. Like Morrison and Lumby, the focus of this paper is upon investigating how leadership played out in FE. Unlike these authors however, in this project the FE leaders in question took on the role of ethnographers not the project team.

\footnotetext{
${ }^{1}$ Although outside the scope of this paper, the research team defined innovative governance as a means of considering and facilitating transition and positive change as a board that will benefit the organisation as a whole.

${ }^{2} \mathrm{FE}$ in England provides technical and professional education and training for young people, adults and employers and takes place post compulsory participation in education.

${ }^{3}$ All informants and organisations mentioned in this paper have been given pseudonyms to provide confidentiality.
} 
The paper examines how the informants experienced being a governor ethnographer and what this revealed to them about their identity as a FE governor and understandings of FE governance. This paper does not report per se on the findings regarding FE innovative governance which are the focus of a further report. Rather, it examines what the governor ethnographers discovered about themselves as both governor and ethnographer, and the environment in which their board operated.

The paper explores the physical environment of the FE sector in England. However, it also examines the policy environment in which these governor ethnographers undertook their enquiry. Most notably, the paper examines how high-stakes neo-liberal performative (Lyotard, 1979; Ball, 2003) and Panoptic (Foucault, 1977) conditions formed what these governors did, what FE governance meant, and how an ethnographic lens revealed to the informants a whole raft of new understandings.

\section{The project}

The governor ethnographer project formed part of the larger Innovative Governance in FE project (InnGov) project - conducted between 2015 and 2016 - which was funded by the Further Education Trust for Leadership (FETL). As part of InnGov, the research team met with and interviewed a large number of informants (see Tabe.1). All governors who were members of the wider InnGov cohort, were given the opportunity to attend three 'ethnographic research' professional development (CPD) sessions (see Cain and Harris, 2013) - nine came to the training and four took up the invitation to become governor ethnographers.

\section{TABLE 1 HERE.}




\section{Table 1. Project Informants}

In these CPD sessions, the governor ethnographers engaged with sections of a Masters level ethnography research methods module. The aim was to give the governor ethnographers an understanding of ethnographic research methods so as they could go into the field and examine how innovative governance played out in their boards. All four governor ethnographers had access to the project team staff whose role was to provide individual support and to act as a 'sounding boards' for ideas.

Project team member were also critical friends - the governor ethnographers were not told 'how to do it', but instead critical friends supported the governor ethnographers through a process of challenging thinking, clarifying approaches and addressing technical queries. Contact was maintained by email and telephone, throughout the project lifespan. Additionally, three further sessions were organised at the university which the governor ethnographers attended. These sessions had two purposes:

- To give the governor ethnographers an opportunity to share what they had 'found out' about innovative governance.

- To give the governor ethnographers an opportunity to share their experience as a governor.

It is important to stress that the governor ethnographers were highly experienced individuals in the worlds of work and governance (see Table. 2).

\section{Table 2 here}

Table. 2 Governor Ethnographer information 
All of the governor ethnographers had a wealth of experience in both business and education, and saw their role as a FE governor as a chance to give something back to the community. Despite this experience, only one of the governor ethnographers described themselves as researchers, again, only one had formal research training, and none had any previous experience of conducting ethnographic research in the field prior to the project.

\section{Why governor ethnographers?}

The project context leads to examining the justification for pursuing the governor ethnographer route. There are well-rehearsed methodological considerations which examine some of the deep-seated considerations concerning ethnography (Hammersley, 2006: Jeffrey and Troman, 2004; Walford, 2009). However, there appears to be relatively little research which follows the novel approach outlined in this project, although there have been examples of action researchers following a similar model (see for example Cain and Harris, 2013).

It is not the focus of this paper to examine the merits and pitfalls of ethnography. However, it is important to consider why ethnography was used in this case. In doing so, there are two main considerations:

- Physical/policy/emotional access

- Story making and storytelling

One of the most impactful findings for the research team - who have worked on a number of projects in the FE sector - was the willingness with which FE informants discussed their work, experiences and understandings. At the beginning of the project, the team's major concern was that no one would want to be a governor ethnographer. It was just this willingness for people in the sector to discuss and examine their practice 
which led to the first consideration as to why governor ethnographers would form the project's approach to data generation and analysis, that is, access.

The main consideration, and indeed challenge, regarding access was not what the research team first expected. Rather than issues with gaining access, the research team was overwhelmed with offers to attend board meetings, interview governors, shadow the work of clerks and speak to principals. Indeed, the number of offers far outweighed the team's capacity. However, what was a significant focus of the research was to obtain the 'insiders' view (Webster and John, 2010) on FE governance. To do so, members of the research team could have taken on the role of governor themselves - a course immediately rejected and fraught with ethical challenges.

Therefore, rather than the outsider researcher (see, Wegener, 2014) attempting to become an insider, the focus was upon supporting an insider to become an ethnographic researcher. What the team hoped was that governor ethnographers would gain not just the physical access afford to the research team, but the emotional access built upon trust and collegiality - what Jachrya et al (2015) described as rapport making - which had developed over many years.

The second element of mobilising ethnography is the power of narratives and particularly story making and storytelling as research. The paper draws on Clough's (2002, 2009) work, where he examines how ethnographic stories reveal a deeply personal and revealing version of events. Clough $(2009,347)$ laments that with 'increasing emphasis on the metrics of publication output and funding won, we work at the edges of methodological boundaries'.

For Clough, within the performative environments facing not just FE governors but also researchers, rather than 'cold scholarship' there is a need for the humanity inherent in narrative accounts. Consequently, this paper values the storytelling of the FE 
governor ethnographers as a means of navigating the complexity of the governance world.

As Clough (2009, 347-348) suggests:

Some things are more visible than others; ask me to measure, say, the success of a school, or its behaviour policy; to describe through my enquiries the experiences of disaffected youth ...I will do this for you, and publish my report if you wish. But some things are not to be had this way, and must be approached more subtly, with an oblique vision.

\section{Meta-level ethics}

The British Educational Research Association (BERA, 2011) ethical framework was adopted to ensure anonymity and protection of the informants all of whom self-selected to participate. Additionally, the project drew on ethnographic literature which explored ethics (see for example, Beach and Erickson, 2010) so as to develop an overview of different methodological and ethical approaches. As a result of this process, the project could be described as an example of meta-level ethics. In other words, there were the ethical considerations concerning:

- the project team and the ethnographers

- the ethnographers and fellow governors

In practice, what the team felt might be a difficulty did not prove to be so. The project team went through the usual process of sharing the research aims, withdrawal, data protection and outputs with the governor ethnographers, all of whom signed the appropriate ethics form. The governor ethnographers then went through the same process with their governor colleagues, whilst stressing that any data would be analysed both by the governor ethnographers and the project research team.

Again, all governors present in the meeting were asked to sign an ethics form which all did. So as to signpost the project, the ethnographers followed the same approach 
of forwarding an agenda item outlining the research for discussion by the board prior to data generation.

\section{Performativity and panoipticism}

Before examining the empirical evidence, it is first necessary to briefly examine the relationships between performativity, panoipticism, ethnography and governance. Both ethnography (see, Avis, 1997; Clapham, 2013; Puttick, 2015) and governance (see, Gleeson and Shain, 1999; Glesson et al, 2011; Hangartner and Svaton, 2014) have been examined in terms of how neo-liberal market forces have impacted upon them. As Puttick $(2015,1)$ writes:

\footnotetext{
Performativity raises...issues which may demand particular responses from ethnographic researchers, whose empathetic intention places them well to explore and critically engage with - the workings and effects of performativity.
}

Common in this literature was that the high-stakes and highly regulated performative landscapes in which both governance and ethnography inhabit, have had the effect to fundamentally re-orientate both activities.

For Lyotard, performativity is the drive for, and analysis of, efficient production and the 'optimisation of the global relationship between input and output' (Lyotard, 1979, 11). Moreover, performativity engenders environments where 'hard facts' are the predominant currency. Lyotard described performativity as being reflected by, and reflecting, the 'legitimacy' of knowledge through scientific (23) rather than narrative (18) discourses. Lyotard's view was that performativity elevated the scientific knowledge of statistics and evidence above the narrative knowledge of stories and experience.

The neo-liberal marketisation and performative facing contexts of public sector organisations such as FE, has led to the wholescale application of accountability measures originally seen in commercial situations (Ball, 2012). For Lyotard (1979, 15), these 
regulatory mechanisms are necessary due to the constant 'self-adjustments the system undertakes in order to improve its performance' which are inherent in performative structures.

Performative self-regulation has resulted in conditions where inspectors, policy makers, ministers and the market defines educationists' work (Ball, 2003). Fundamental to performativity are self-regulatory measures - more of which when Panopticism is considered - which reflect the neo-liberalisation of macro-level education systems and meso-level organisations such as FE colleges (James and Biesta, 2007).

Performative self-regulation and accountability are achieved through the use of metrics to represent the efficiency of an organisation which are mapped against both benchmarks and competitors (Perryman et al, 2011). Crucially, the disciplinary and transformative elements of performativity lead external regulatory systems such as inspection to be embedded in the practice of those within the organisation (Perryman, 2006; 2009).

However, both self-regulatory mechanisms borrowed from the private sector, and performative discourses, make fundamental assumptions regarding the effectiveness and efficiency of the private sector in contrast to the inefficiency and ineffectiveness of the public sector (Ball, 2008). These assumptions have led to private sector technologies of production - such as performance management - being applied to public sector organisations such as education and health.

A corollary to performativity is Foucault's (1977) work on the Panopticon. Foucault explores the processes of surveillance through using the metaphor of the Panopticon prison. In the Panopticon, merely the threat of constant observation controlled the actions of those toward which the threat of surveillance was directed. Foucault's work 
on the Panopticon, inspection, and what he calls 'disciplinary power', has been used to examine educational settings (see Perryman, 2006; Clapham, 2015b).

The Panopticon metaphor reveals inspection as part of the neo-liberal and performative approach to education through what Perryman (2006) describes as panoptic performativity. Panoptic performativity mobilises inspection technologies - such as OfSTED - so as to create conditions of 'total surveillance'. In other words, the inspector is present in actors' actions and discourses even when not physically present through regulatory measures such as mock inspections, or 'mocksteads' (see Clapham, 2015c).

Surveillance and panoptic performativity underpin disciplinary power. By disciplinary power, Foucault means there is a construction of rules and norms of conduct where individuals are rewarded, or punished, for conforming to or deviating from these norms. Foucault $(1977,156)$, highlights that disciplinary power is 'natural and organic' with the result that those who are subjected to disciplinary power are also its agents.

Disciplinary power underpins the self-modification of an inmate's behaviour as they become 'the principle of his [sic] own subjection' (Foucault, 1977, 203). Foucault's position is that behaviour is modified as a precursor to any disciplinary action. Those within disciplinary power discipline themselves 'because the constant pressure acts even before the offences, mistakes or crimes have been committed, (206). For Foucault, the permanent visibility of the Panopticon is a metaphor for disciplinary systems which have been applied across a range of societal structures.

Examining both governance and ethnography through referencing performativity and panopticism gives a view on how macro-level neo-liberal structures play out in the day-to-day activities of governing FE colleges and conducting qualitative research. Exploring how FE governors mobilised ethnography as a tool with which to examine their practice, and that of their boards, has been done with an acknowledgement of the context 
in which this process took place. In doing so, some of the 'stresses and strains' facing FE governors and governance are revealed. Similarly, exploring how ethnographic study was mobilised, and valued, in the high-stakes world of FE governance gives an insight into what qualitative research means to those outside of the ethnographic research community.

\section{Research methodology}

The project's research methodology had two stands:

1. generating and analysing data relating to the governor ethnographers' findings regarding innovative governance

2. generating and analysing data relating to the governor ethnographers' experiences of being an ethnographer

The primary data generation tool was reflexive interviewing (Kvale and Brinkman, 2008) which was supplemented with the examination of documentary evidence (official, public and personal) in the form of board meeting agendas and minutes, and the governor ethnographer participant observation fieldnotes (see Hammersley, 2006). Kvale and Brinkman, 2008 suggest that reflexive interviewing is a process:

- Laden with ethical issues

- Embedded in social and historic context

- Involves asymmetrical power relationships between interviewer and interviewee

Drawing on Kvale and Brinkman's work (2008), reflexive interviewing was employed for the project due to the sensitive and confidential nature of some of the conversations which took place and the professional standing of those being interviewed. The governor ethnographers were interviewed separately, and as a focus group, on a range of issues which emerged from the research process. The overarching research question was: 
- How did the process of ethnographic enquiry play out for FE governors?

There were also a range of subsidiary questions which were revisited during the duration of the project and which were asked during interviews and the focus group:

- Where would you place yourself on the continuum of total observer to total participant? (see Gold, 1958)

- What is it like to be an ethnographer during a board meeting?

- What about objectivity in ethnography?

- Have you come across any ethical and/or moral dilemmas as an ethnographer?

As outlined earlier, the research team did not observe the governor ethnographer board meetings. Although doing so would have added an extra dimension to the research, the project team were equally concerned that their presence would skew the very interactions, discourses and behaviours which were hopped to be observed. Moreover, due to the items under discussion there would be frequent agenda items where access would not be granted to an outsider (see Ely, 1991) - access which was granted to the 'insider' governor ethnographers.

The governor ethnographers however, spent a significant part of their fieldwork conducting observations of the working of their boards. As Kelly et al (2006) indicated, observations of FE management meetings were pivotal events in understanding how leadership played out, and as Morrison and Lumby, $(2009,73)$ suggest:

...meetings were valued as a research arena where first, it might be expected that dispersed, collective, or indeed diverse acts of leadership would be more rather than 
less discernible, and second, as potential theatres for performance in which the most overt forms of leadership might be displayed through talk.

None of the governor ethnographers chose to use an observation schedule. The rejection of observation schedules was for pragmatic reasons in that contributing to, and in some cases chairing, a board meeting precluded the use of such tools. Consequently, the governor ethnographers followed Delamont's (1976) model of unstructured observations. Rather than 'ticking off' observed phenomena against prepared checklist of events, the governor ethnographers engaged in a reflexive process of identifying events which appeared to be of interest and then capturing the essence of these event in fieldnotes. These field notes were analysed, both by governor ethnographer and the project team, so as to ascertain an understanding of how the board meetings played out.

On this point of data, it is important to be as explicit as possible to prevent misunderstanding or ambiguity (see Hammersley and Atkinson 1995). In none of the cases reported did the governor ethnographer audio-record events ${ }^{4}$. Indeed, there were occasions when not even note-taking was possible in the meeting - when the governor ethnography was chairing or presenting an agenda item for example. Therefore, drawing on Woods (1996), data in the text is identified as to whether generated from an interview (i.e. a transcript of an audio-recorded interview between research team member and governor ethnographer); a field note (i.e. a governor ethnographer's reflexive recording of a conversation) or an observation (i.e. a governor ethnographer's reflexive recording of an observed event).

Grounded theory was mobilised as the analytical framework (Strauss and Corbin, 1998; Charmaz, 2005). The analysis consisted of coding data and the identification of

\footnotetext{
${ }^{4}$ Interviews between governor ethnographer and the research team were audio-recorded and transcribed.
} 
concepts (discreet phenomena) and categories (linked groups of similar phenomena) - see

Table. 3. The process of coding was not a distinct singular stage but was a continuous part of the analytical process (Strauss and Corbin, 1998). The grounded theory process of coding data informed future areas of investigation, hypotheses developed and questions asked (see Glaser and Strauss, 1967).

\section{Table 3 here}

Table 3. Grounded theory analysis concepts and categories

\section{Discussion}

As indicated in Table 3, three main categories emerged from the analysis (1) am I doing it right (2) A friendly spy and (3) an altered lens. Each of which are now examined.

\section{“...am I doing it right"?}

Prominent in the governor ethnographer data was a concern that they were, as Chris put it, "doing it right". What emerged however, was that the initial worry regarding 'how to do ethnography' was soon replaced by a concern that ethnography did not appear to fit within the high-stakes and 'hard' fact driven environments of their boards. This concern reflected the governor ethnographers' struggle to resolve how, what Ian called "uberqualitative" ethnography, fitted into a context where quantitative data was increasingly afforded the position as being the 'gold standard' in evidence.

So as to examine the governor ethnographers' research identity - and with it to develop and understanding of how ethnography played out in their boards - the governor ethnographers were asked to position their identity as an ethnographer on Gold's (1958) total participant-total observer continuum. What this process revealed was the variation 
in how the governor ethnographers identified themselves as researchers in the field, and what this identity meant for justifying ethnography as a 'valid' research methodology.

Whilst Ian, Sahida and Sally identified with the total participant end of the continuum Chris and Oliver identified with the total observer. Moreover, this process highlighted how the governor ethnographers felt that the context of the board meeting, and their role in it, impacted upon this identity:

[As a] participant observer... as well as filtering what is going on, so you are taking part you are listening, you are watching you are making whatever contribution you need to make. (Sahida, Focus group interview)

Chris felt that the specific context of meeting was the deciding factor as to the degree to which he was observer or participant:

I attended a committee meeting as a total observer. I found it easier than juggling participation with observation to be completely absorbed in what was happening. (Chris, Field note)

The data relating to identity became increasingly important particularly, when considering how the governor ethnographers' identity played out in the performative high-stakes environments in which they were board members. For example, all the governor ethnographers reported that they needed to position ethnography as 'scientifically' as possible to their boards. In other words, for ethnographic data to be given credence by other board members the governor ethnographers felt they had to talk in terms of method, reliability, validity, generalisations and objectivity:

I spoke about ethnographic science to the board....and I suppose, that' show I thought about it anyway...that it had to be a science. But, I felt it was really important to talk about objectivity in the process...but now of course and I can't see how an ethnographer can be objective. (Sally, Field note) 
All of the governor ethnographers felt that if ethnography was to have credibility it was couched in the terms of 'hard' science and that this was reflected in the language that was employed:

You could if you felt confident enough speak in the language of ethnography and tell your audience, in this case the corporation, what are you doing in the language of ethnographic science...(Sally, interview)

The governor ethnographers reported that they had ceased to worry about how 'well' they were 'doing' ethnography. This worry was replaced with a deep concern that such a qualitative approach did not appear to sit within performative contexts and had to be almost rebranded as a 'hard' science to be given credibility:

...in presenting that we were doing this ethnography thing to my board, I had to speak in a certain way to make it sound justified, appropriate, decent. (Ian, interview)

The governor ethnographers increasingly highlighted the extent to which they feared for the credibility of ethnographic research in times of increasingly 'hard' data and what Lyotard (1979) described as the prominence of scientific rather narrative knowledge in performative contexts.

\section{“...well, I suppose a friendly spy".}

When asked at the beginning of the project to describe an ethnographer, Oliver used the term "friendly spy". What was particularly impactful from the project was the extent to which those involved - governor ethnographers and research team alike - developed their understanding of what ethnography was in the field. Foremost amongst this change was closely linked to the findings relating to ethnography, and its perceived worth, in performative settings. The governor ethnographers' data indicated that it was the 
ethnographer who was being observed, inspected and ranked as much as the setting they were investigating:

I just wonder how much ethnography is taken seriously... When I spoke about it I didn't use the word ethnography deliberately, because I thought if I use that word ethnography any other people have not heard of it before, you could get hung-up on the word. I said participant observation...(Ian, interview)

Parallels between the observation in the field of the ethnographer, and the observation from the central tower in the Panopticon emerged from the governor ethnographers' comments. The view as to the ethnographer being a spy was soon rejected by the governor ethnographers and instead a far more nuanced view was developed. For Sally, the entire worth of qualitative research was at stake:

When I talk about qualitative research I can almost hear the sighs from certain colleagues... (Sally, field note)

Sally's data suggested that although immersed in participant observation, it was ethnography itself which was under inspection by the deep-seated processes of panoptic performativity. There was therefore a tension between the worth of ethnography advocated by the governor ethnographers, and the worth placed upon qualitative research by their boards. As Sally outlined after reading Ian's fieldnotes:

I think it is [the field notes] intriguing and would stimulate any governor to look at the movement and the overall direction of the corporation...I haven't read anything like this and I've read a lot about governance in other sectors. (Sahida, interview)

Despite Sally's comment about the worth of Ian's field notes she was adamant that it would take a particularly forward looking board and chair, to base fundamental change on such ethnographic data. Nonetheless, there was significant data generated by 
the governor ethnographers which they maintained would have significant impact upon the working of their boards. After analysis ng his data, Chris for example wrote:

We're spending too much time regurgitating information, not enough time understanding the 'whys'. (Chris, Field note) ${ }^{5}$

\section{“...it's just an altered lens".}

The final category to emerge from the analysis was one which explored the ethnographic lens. Ian's opening data for this paper illustrates powerfully how for the governor ethnographers, using an ethnographic lens revealed new insights into their practice and that of their boards. Ian's data also illustrates the prominent position of 'hard' facts in the day-to-day discourses of his board. Indeed, like Ian, all the governor ethnographers reported that a positivistic and 'scientific' approach toward understanding their organisation formed the basis of major decision making.

What emerged from the data was that an ethnographic approach revealed highly nuanced aspects of the governance process. In doing so, the governor ethnographers were able to examine some of the complex interactions, relationships, norms and actions which were fundamental in the board's processes. For example, key in the ethnographic data was the significance of power relationships. However, the governor ethnographers indicated that it was not the act of becoming an ethnographer which revealed this data rather, as Sahida stated, "I've been an ethnographer all along...it's just an altered lens".

\footnotetext{
${ }^{5}$ At the time of writing, Chris was in the process of tabling an agenda item where he took this data back to his board so as to effect change as to the processes involved in committee reports and reviewing previous minutes.
} 
Sahida's comments were echoed by Oliver who highlighted that participant observation was a crucial part of being a successful businessman and successful governor:

...it's not unusual that people look around the meeting at the silent folks and simply want to read their expressions. (Oliver, interview)

However, all the governor ethnographers stated that it was not simply a case of looking at what was happening:

...it might be a mistake to think your presence as an ethnographer hasn't effected interactions, affecting the tone of what they do. (Ian, Field note)

It was the notion of effect which was brought out in relation to discussions regarding power relationships. All five governor ethnographers reported that the richness of their data was precisely because they were aware of the backstories which were in play:

I was vice chair for a while and if you look at the power relationship there, it can be this is my club you can come in. It is also about the chair going around beforehand and talking to people you might call it lobbying you might call it something else. (Sally, field note)

...some people take the line with student governors not being as valuable as [in brackets] 'real governors'. (Chris, field note)

What can happen sometimes on a board particularly with men and women, is a woman might say let's set a slight deficit budget in a particular area, and it's not heard, then a man will say we should and then its oh yes we should. These are the power dynamics in the same way that someone could be typecast as they are the tory so they are not listened to. (Sahida, interview)

The nuances inherent in these data reflected for the deep and rich lens which ethnography afforded a research setting. This is not to say that this lens is unproblematic. As previously rehearsed in the governor ethnographers' data, there appeared to be - 
amongst some of their colleagues at least - significant and entrenched resistance to ethnographic research in relation to issues of validity, reliability generalisations and most significantly of all objectivity.

\section{Discussion: Being a governor ethnographer}

At this point it is appropriate to revisit the research question which asked 'how did the process of ethnographic enquiry play out for FE governors?' From examining the data there are two sub-questions which need to be examined so as to answer the research question (1) what did the governor ethnographers learn about their identity as a governor/researcher and (2) what did the governor ethnographers learn about FE governance.

\section{Researcher identity}

When considering the governor ethnographers' researcher identity some of the deeply complex issues of truth, knowledge and evidence need to be examined. Although the inherent nature of the approach means that, as Woods (1996, p. 70) asserts, ethnography is not predetermined and 'chaotic', this does not mean that there is a complete lack of structure. Indeed, in such potentially chaotic circumstances, structure is of the utmost importance.

So as to provide structure, the governor ethnographers were directed toward Troman's (2006, p. 1) 'checklist' of key ethnographic elements with three suggestions being of particular important:

- ...the generation of rich and diverse forms of data

- the recognition that the researcher is the main research instrument

- the high status given to the accounts of participants' perspectives and understandings 
Troman's three main points (1) that ethnographic data is rich (2) that the researcher is the main research instrument and (3) the high status given to the participants' perspectives and understandings both encapsulate the strengths of ethnographic research but also the challenges it faces.

Speaking in 2014 (no page), the then Secretary of State for Education Michael Gove spoke of the need for ministers to embrace a "much more rigorous and scientific approach" to understanding education and with it the rejection of "a faddish adherence to quack theories". Gove then cites the Organisation for Economic Co-operation and Development (OECD) Programme for International Student Assessment (PISA) study as having "transformed our understanding of what works" in education.

Although not explicitly referring to ethnography, it is hard to imagine two more opposing methodologies than that of the ethnographer immersed in the field of a single case, and PISA which in 2012 tested 510,000 students in 65 countries. It is just this tension between the macro-objective PISA, and the micro-subjective ethnography, which illustrates both the governor ethnographers' developing researcher identity and the performative facing environments which they explored.

Avis $(1997,5)$ wrote of the travails of 'leftist ethnography' and its 'relation to educative research [which is]...tied to understandings of the reflective practitioner'. Here Avis again illustrates the tensions between Lyotard's (1979) notion of narrative knowledge such as that generated form ethnographic research, and scientific knowledge such as that generated from large scale quantitative testing of students. For the governor ethnographers, being an ethnographer had fundamental ramifications for how they felt they needed to support their boards to negotiate the high-stakes environments facing the English FE sector. The pre-eminence of scientific over narrative knowledge is vividly illustrated by Chris in a field note: 
I was invited to introduce the research...Some quizzical looks, but I reassured about confidentiality. I was asked if, and how, the report could be useful for us and I said I hoped so. I was pressed on what is ethnography and whether it can work by the professional engineer (Ronnie)...he was bound to question it, on the grounds that as an engineer, he would only believe in a positivist research approach, which is more or less how I responded. He's a nice guy, and takes up his role of challenging the 'politically correct' and management speak, the novel and smartarse in a studiedly world-weary way. Sometimes I join him and we challenge statistics and statistical presentations. No animosity. Between us we are useful grit in bland presentations. (Chris, Field note)

Here, Chris' work justifying the "novel and smartarse" of ethnography to the world weary Ronnie reveals the day-to-day work needed to be completed by the ethnographer. Like Chris, the other governor ethnographers felt that this was work they were willing to take on and an identity they wanted to develop, if it had the desired effect of enabling ethnographic research, data, analysis and - most importantly of all - thinking, to take place not just in FE but in educational settings of all types.

\section{Ethnography and governance}

As outlined at the outset, this paper does not consider the findings regarding the InGov project. However, what it does consider, is what an ethnographic lens revealed to the governor ethnographers which they reported might not have been visible to them previously.

All the governor ethnographers reported that the process of taking on the identity of ethnographer mediated them to develop a new, nuanced and powerful lens upon governance. Of course, the accusation made might be 'well they would say that wouldn't they'. It is important to stress therefore, that the governor ethnographers had no vested interest in exhorting the virtues of ethnography. They received no incentives to take part, they were all extremely busy people with numerous high-level responsibilities, and as 
was highlighted at the project start, they were able to withdraw from the project whenever they wished - none chose to do so.

What their commitment to the project illustrates, was the worth that the governor ethnographers put not just on this project but on the importance of ethnographic research across the piece. It is necessary here to take a moment to consider context. Along with many other public sector areas, English FE faced significant challenges during the time of this project. For example, a reduction of $24 \%$ in funding for FE in England was made in 2015 with the Association of Colleges (AOC, 2014) suggesting that these were an 'unjust an unsustainable' approach to funding the sector. Additionally, the Department for Business, Innovation and Skills (BIS) and Department for Education (DfE) instigated FE Local Area Reviews (LAR) with the then Skills Minister Nick Bowles (2015, no page) questioning the very future of FE funding and warned that "difficult choices" had to be made.

Within this context therefore, the performative nature of LARs which very much focused on survival of the fittest was brought into stark relief. As Bowles (2015, no page) outlined, LARs highlighted the challenge's facing the "less productive bits" of the FE sector - 'bits' that some of the governor ethnographers in this project were board members of. As Ian described in a field note:

We are talking about a reality that is really quite extreme...you are immediately limited by practicalities, but driven by political desire. (Ian, Field note)

What Ian's data reflects is how the process of engaging with ethnography was not a 'golden bullet' for the governor ethnographers. As Ian outlined at the beginning of this paper, he had "always noticed". What the governor ethnographers did report, was that this methodological lens engendered a deep sense of reflection. Again, all the governor ethnographers were deeply reflective people, prior to this project. They maintained 
however that the day-to-dayness of leading FE collages facing extraordinary challenges led to, as Sally said, reflection being "put on the back-burner".

It was just this reflective lens which the governor ethnographers maintained was required more than ever during such challenging times. As Sahida outlined, it was reflection upon what was happening day-to-day in her college which countered the looming spectre of the performative technologies of inspection - technologies which she and the other governor ethnographers maintained had led to the prevalence of an overbearing "rear-view mirror" perspective upon governing, and governance, across the FE sector.

\section{Ethnography in peril?}

At the outset this paper asked how the process of ethnographic enquiry played out for FE governors. In answering this question, the paper has explored both governance and research. The result of this exploration - perhaps not unsurprisingly considering the context in which the project took place - is stark. Performativity appeared to be ingrained in the work of the FE colleges under investigation. As a result, performativity not only directed what went on day-to-day but also what was considered to be 'best' knowledge with which to evidence 'best' practice.

As such, it was impossible to disentangle the requirements of educational institution attempting to negotiate neo-liberal and performative conditions from what counted as data and valid research. Drawing on Lyotard's (1979) notion of scientific knowledge being prevalent over narrative knowledge in performative systems reveals some of the 'real-world' challenges which the governor ethnographers faced. Justifying ethnography required the governor ethnographers to take on a researcher identity which was in many ways in direct opposition to the identity of the 'valid' researcher held by both neo-liberal education systems and government policy. 
Nonetheless they did so. This was both a brave and heartening decision. As stated previously, the governor ethnographers had no incentive to preserver with the project. That they did so suggest that they found ethnography inherently of worth, and worthy, or pursuing. Of course it would be wonderful to report how all the boards, and board, members involved in this project took on ethnography and embraced it as a worthwhile and valid research approach. This was not the case. The governor ethnographers reported, perhaps unsurprisingly, continued scepticism toward ethnography being demonstrated by board members at the end of this project.

It is this entrenched scepticism which highlights the challenges for ethnographic research in performative settings. Jeffrey and Troman wrote of 'compressed' $(2004,538)$ ethnography. That is, the deployment of ethnographic frameworks but over a shorter time frame than exhibited in the 'classical' ethnographies of say Stephen Ball (1981). This is a fundamental point - just because the demands of performativity appear to be making ethnography challenging to both justify and conduct does not mean that the ethnographic research community should simply give up. If compressed ethnography means that ethnographic enquiry takes place, then this appears to be the most logical course of action. Woods (1996, p. 70), described ethnography as an act of faith:

[Ethnography]...is an open approach, not pre-determined, inductive more often than deductive, with theory generated and grounded in the data. Ethnographers do not know what they will find. Initial work is typically messy and chaotic, until themes begin to emerge. Ethnography is an act of faith, requiring strong initial commitment. Some prefer the security of more systematic methods.

From exploring the experiences of the governor ethnographers in this project it seems more than ever that such faith is needed by the ethnographic community. However, despite the challenges facing the ethnographer there is some 'good news'. Feather (2012) pondered if there was a desire to conduct research in $\mathrm{FE}$ - the answer to this question form 
the governor ethnographers in this paper was a resounding yes.

It seems therefore that, in the cases reported here at least, there are those who are prepared to take Wood's act of faith. This paper began with data and it finishes with data. The 'worth' of ethnographic enquiry is reflected in the actions of the governor ethnographers reported here. And powerfully illustrated by Sally's comments:

\footnotetext{
Reading your observations really makes me think, your way of doing it [ethnography] doesn't mean that it's right or wrong or I want to copy it. It makes me think about layers of activity and ways of operating that normally I wouldn't usually think about... you think what's the topic, what's the business, how are we going to get through it. It makes me think about the power of the executive, who sets the tone for the questions, the interplay is very interesting. (Sally, Governor)
}

The work of the governor ethnographers has facilitated a unique lens upon what they do as governors, and what they do as ethnographic researchers. Their work, and the approach of the entire project, is clearly up for critique. However, what has emerged strongly form their experiences is that ethnography is alive, well, and contributing powerful to understanding the complexity of social interactions despite the challenging circumstances increasingly facing qualitative educational research.

\section{References}

AOC, 2014, Association of Colleges calls for Government to stop 'unsustainable' cuts to college student funding. https://www.aoc.co.uk/news/association-colleges-callsgovernment-stop-\%E2\%80\%98unsustainable\%E2\%80\%99-cuts-collegestudent-funding. Accessed 18/3/15

Avis, J. 1997. Leftist ethnography, educative research and postcompulsory education and training, Research in Post-Compulsory Education, 2(1): 5-16

Ball, S. 1981. Beachside Comprehensive: A Case Study of Secondary Schooling Cambridge: Cambridge University Press. 
Ball, S. 2003. The teacher's soul and the terrors of performativity. Journal of Education Policy 18(2): 215-228.

Ball, S. 2008. New philanthropy, new networks and new governance in education, Political Studies, 56: 747-765.

Ball, S., Maguire, M., and Braun, A. 2012. How Schools Do Policy: Policy Enactments in Secondary Schools Abingdon: Routledge

Beach, D., and Eriksson, A. 2010. The relationship between ethical positions and methodological approaches: a Scandinavian perspective, Ethnography and Education, 5(2): 129-142,

Bowles, N. 2015. Bowles: government faces 'difficult choices' over future of colleges. Times Education Supplement. https://www.tes.com/news/furthereducation/breaking-news/boles-government-faces-difficult-choices-over-futurecolleges

British Educational Research Association (BERA). 2011 Ethical guidelines for educational research. http://content.yudu.com/Library/A1t9gr/BERAEthicalGuideline/resources/index .htm?referrerUrl=http\%25253A\%25252F\%25252Fwww.yudu.com\%25252Fite m\%25252Fdetails\%25252F375952\%25252FBERA-Ethical-Guidelines-2011 accessed July 2014

Cain, T, and Harris. R., 2013. Teachers' action research in a culture of performativity, Educational Action Research, 21(3): 343-3

Charmaz, K. (2005). Grounded Theory in the 21st Century. In N. Denzin and Y. Lincoln (Eds.), Handbook of Qualitative Research (3rd ed.). Thousand Oaks: Sage.

Clapham, A. 2013. Performativity, fabrication and trust: exploring computer-mediated moderation, Ethnography and Education, 8(3): 371-387 
Clapham, A. 2015a. Post-fabrication and putting on a show: examining the impact of short notice inspection. British Educational Research Journal. 41(2): 613-682

Clapham, A. 2015b. Producing the docile teacher: analysing Local Area Underperformance Inspection. Cambridge Journal of Education. 45(2): 265-280

Clapham, A. 2015c. "Answer your names please": a small scale exploration of teachers technologically mediated 'new lives'. Teachers and teaching. Theory and Practice. 21(6): 366-378

Clough, P. 2002. Narratives and fictions in educational research. Buckingham, UK: Open University Press.

Clough, P. 2009. Finding God in Wellworth high school: more legitimations of storymaking as research, Ethnography and Education, 4(3): 347-356,

Delamont, S. 1976. Beyond Flanders Fields: The Relationship of Subject Matter and Individuality to Classroom Style. In Explorations in Classroom Observation, M. Stubbs, and S. Delamont (Eds), 101-131. London: John Wiley and Sons.

Ely, M. 1991. Doing Qualitative Research: Circles within Circles. Philadelphia, PA: Falmer Press.

Feather, D. 2012., Do lecturers delivering higher education in further education desire to conduct research? Research in Post-Compulsory Education, 17(3): 335-347

Foucault, M. (1979). Discipline and Punish: The Birth of the Prison London: Penguin

Gleeson, D., and Shain, F. 1999. By Appointment: governance, markets and managerialism in further education. British Educational Research Journal. 25(4 ):545-561

Gleeson, D., Abbott. A, and Hill. R. 2011. Governing the governors: a case study of college governance in English further education. British Educational Research Journal. 37(5): 781-796 
Gold, R. L.1958. "Roles in Sociological Field Observation.” Social Forces 36 (3): 217223.

Gove, M. 2014. Michael Gove speaks about the future of education reform. https://www.gov.uk/government/speeches/michael-gove-speaks-about-thefuture-of-education-reform

Guba, E. and Lincoln, Y. 1994. Competing Paradigms in Qualitative Research. In Denzin, N., and Lincoln, Y. (Eds.). (2005). The Sage Handbook of Qualitative Research (2nd ed.). London: Sage.

Hammersley, M., and P. Atkinson. 1995. Ethnography: Principles in Practice. 2nd ed. London: Routledge

Hammersley, M. 2006. Ethnography: problems and prospects. Ethnography and Education. 1(1): 3-14

Hangartner, J and Svaton C-J., 2014, Competition between public supervision and professional management: an ethnographic study of school governance reforms in Switzerland, Ethnography and Education, 9(3): 284-297

Jachyra, P, Atkinson, M, and Washiya, Y., 2015. 'Who are you, and what are you doing here': methodological considerations in ethnographic Health and Physical Education research, Ethnography and Education, 10(2):242-261

James, D. and Biesta, G., 2007. Improving learning cultures in further education. London and New York: Routledge.

Jeffrey, B. and Troman, G. 2004. Time for ethnography. British Educational Research Journal, 30(4): 535-548

Kelly, S., M. Iszatt White, and M. Rouncefield. 2006. Meetings as the practical accomplishment of educational leadership. International Studies of Educational Administration 34(2): 4661. 
Kvale, S., and S. Brinkman. 2009. Interviews. Learning the Craft of Qualitative Research Interviewing. London: Sage

Lyotard, J. 1979. The postmodern condition: A report on knowledge (G. Bennington and B. Massumi, Trans.). Manchester: Manchester University Press.

Morrison, M and Lumby, J., 2009. Is leadership observable? Qualitative orientations to leadership for diversity. A case from FE, Ethnography and Education, 4(1): 6582 ,

Perryman, J. S, Ball, M, Maguire and A, Braun. 2011. Life in the Pressure CookerSchool League Tables and English and Mathematics Teachers' Responses to Accountability in a Results-Driven Era, British Journal of Educational Studies, 59(2): 179-195,

Puttick, S. 2015., Performativity, guilty knowledge, and ethnographic intervention, Ethnography and Education, DOI: 10.1080/17457823.2015.1110039

Strauss, A. 1987. Qualitative Analysis for Social Scientists. New York: Cambridge University Press.

Strauss, A., and Corbin, J. 1998. Basics of Qualitative Research: Techniques and Procedures for Developing Grounded Theory. Thousand Oaks: Sage.

Troman, G. 2000. Teacher stress in the low-trust Society. British Journal of Sociology of Education 21, (3): 331-353.

Troman, G. (2006). Editorial. Ethnography and Education. 1(1): 1-2

Walford, G. 2002. Doing a doctorate in educational ethnography. Studies in educational ethnography. Vol. 7. Oxford, UK: JAI Press.

Walford, G. 2009. For Ethnography. Ethnography and Education. 4(3): 271-282 
Webster, J-P and Arevgaq John, T., 2010. Preserving a space for cross-cultural collaborations: an account of insider/outsider issues, Ethnography and Education, 5(2): 175-191,

Wegener, C. 2014. 'Would you like a cup of coffee?' Using the researcher's insider and outsider positions as a sensitising concept, Ethnography and Education, 9(2): 153-166,

Woods, P. 1996. Researching the Art of Teaching: Ethnography for Educational Use. London: Routledge 